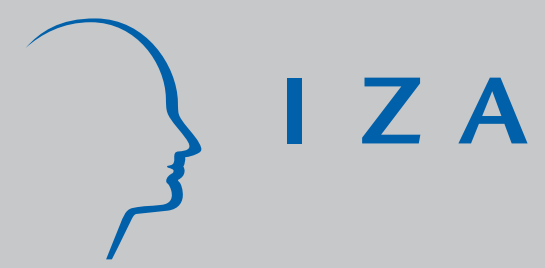

IZA DP No. 8196

Local Funds and Political Competition: Evidence from the National Rural Employment Guarantee Scheme in India

Bhanu Gupta

Abhiroop Mukhopadhyay

May 2014

Forschungsinstitut zur Zukunft der Arbeit Institute for the Study of Labor 


\title{
Local Funds and Political Competition: Evidence from the National Rural Employment Guarantee Scheme in India
}

\author{
Bhanu Gupta \\ University of Michigan, Ann Arbor \\ Abhiroop Mukhopadhyay \\ Indian Statistical Institute \\ and IZA \\ Discussion Paper No. 8196 \\ May 2014 \\ IZA \\ P.O. Box 7240 \\ 53072 Bonn \\ Germany \\ Phone: +49-228-3894-0 \\ Fax: +49-228-3894-180 \\ E-mail: iza@iza.org
}

\begin{abstract}
Any opinions expressed here are those of the author(s) and not those of IZA. Research published in this series may include views on policy, but the institute itself takes no institutional policy positions. The IZA research network is committed to the IZA Guiding Principles of Research Integrity.

The Institute for the Study of Labor (IZA) in Bonn is a local and virtual international research center and a place of communication between science, politics and business. IZA is an independent nonprofit organization supported by Deutsche Post Foundation. The center is associated with the University of Bonn and offers a stimulating research environment through its international network, workshops and conferences, data service, project support, research visits and doctoral program. IZA engages in (i) original and internationally competitive research in all fields of labor economics, (ii) development of policy concepts, and (iii) dissemination of research results and concepts to the interested public.
\end{abstract}

IZA Discussion Papers often represent preliminary work and are circulated to encourage discussion. Citation of such a paper should account for its provisional character. A revised version may be available directly from the author. 


\section{ABSTRACT \\ Local Funds and Political Competition: Evidence from the National Rural Employment Guarantee Scheme in India*}

This paper examines how local politics affects public fund allocations. It uses the context of the National Rural Employment Guarantee Scheme (NREGS) in India which was introduced by the Indian National Congress (INC). Using longitudinal data on funds sanctioned and election results from three rounds of elections in Rajasthan, a state in India, we find an inverted U-shaped relationship between existing vote share of INC and subsequent fund allocations at the block level. To address the issue of endogeneity, we instrument vote shares by their lagged values. The results using only close elections are however distinct as higher funds are allocated to blocks where the INC has lower vote share. We give evidence of a mechanism which highlights the role of a political representative in the funds sanctioning process. Further, we show that the strategy by INC was beneficial in gaining vote share.

JEL Classification: D72, J08, H53, H75

Keywords: political economy, local elections, National Rural Employment Guarantee Scheme

Corresponding author:

Abhiroop Mukhopadhyay

B 10

Indian Statistical Institute

7 S.J.S. Sansanwal Marg

New Delhi 110016

India

E-mail: abhiroop@isid.ac.in

\footnotetext{
* This project is jointly funded by the Effective States and Inclusive Development Research Centre (University of Manchester), the European Union's Seventh Framework Programme for research, technological development and demonstration under grant agreement no 290754 (NOPOOR), the Centre de Science Humaines and the Planning and Policy Research Unit (Indian Statistical Institute, Delhi). We wish to thank the participants at the 9th Annual Growth and Development Conference (Delhi, 2013), ESID Workshop (Delhi, 2013), Conference on MGNREGS (Mumbai, 2014) and seminar participants at Institute of Developing Economies (Tokyo, 2014). We also thank Bhaskar Dutta, Himanshu, Dilip Mookherjee, Nishith Prakash and Kunal Sen for insightful comments. The views expressed in this publication are the sole responsibility of the authors and do not necessarily reflect the views of the funding agencies.
} 


\section{Introduction}

Central governments, all over the world, often introduce flagship public schemes that not only have large budgetary outlays, but lead people to identify the scheme with a particular political regime. For example, Bolsa Familia in Brazil, is often identified with the Lula administration and is believed to have resulted in his victory in presidential elections in 2006. Similarly, the National Rural Employment Guarantee Scheme (NREGS), which guarantees 100 days of employment to rural households in India, is a flagship program of the Indian National Congress party (INC) and was touted to be one of the main reasons for INC getting re-elected to the central government in 2009.

In the context of developing countries, the NREGS is an interesting experiment in policy implementation since it requires active participation of elected local representative bodies in rural areas (called the panchayati raj institutions: PRI). While such decentralization, in principle, may lead to better implementation, it also lends itself to local capture. These can often take the shape of elites getting disproportionate share of benefits from a scheme, especially when the beneficiaries are uninformed about the scheme (Bardhan and Mookherjee, 2000). At the same time, policy implementation can also be affected by local political competition: in particular competition between parties in local elections. Political will to implement the scheme can, in principle, be driven by ideologies of parties (as captured by Candidate-Citizen models of Besley and Coate, 1997). However, recent evidence finds that political opportunism can often dictate how policies get implemented. For example, Bardhan and Mookherjee (2010), in the context of West Bengal in India, finds that areas which are subject to close legislative assembly elections often see better implementation of land reforms. They find that the relation between implementation and political strength (in terms of seats) is an inverted U, with parties not caring about policy implementation if they have a very low or very high representation in an assembly constituency.

In the context of NREGS, there is no major ideological difference between the major parties about the scheme per $\mathrm{se}^{1}$; the difference in posture, if any, has more to do with the fact that the rural polity may identify the scheme with INC since it is one of its flagship programs. This may decrease the will of other political parties to implement the scheme. This leakage of benefits (or lack of it) when parties implement policies has been studied in the context of centre-state transfers. For example, Arulampalam et al. (2009) study the impact of national and

\footnotetext{
${ }^{1}$ The major parties of India are largely left of centre, especially in the context of the rural economy. The differences in rhetoric come largely from posturing during elections. For an interesting take on this issue, refer to http://debrajray.blogspot.in/2013/08/namomania.html
} 
state assembly compositions on centre-state transfers. In their context, the goodwill from centre to state transfers is lost to "leakage" if the government at the state and centre are from different parties. This affects the transfers the centre is willing to make to the state. The case of NREGS is similar. While the scheme is largely funded by the centre, the funds are channelled through local bodies that may have key political personnel who are not aligned to the party at the centre. Hence, this paper explores whether the funds allocated at the local level are affected by local political competition.

The analysis presented in the paper uses data from two panchayat samiti elections (in 2005 and 2010) and NREGS fund allocation to all blocks for the years 2009 and 2012 in Rajasthan, a state in India. ${ }^{2}$ Confounding determinants of demand for funds are controlled for by using block level data from 2001 and 2011 census. Moreover, we carry out block level fixed effects estimation and allow for appropriate trends. We model the funds allocated to a block as a function, among others things, of the existing vote share of the Indian National Congress (INC). To allay concerns of endogeneity, vote shares in each election are instrumented for by the lagged vote share (from the elections held in 2000 and 2005). Results show a concave (inverted U) relationship between the vote share of INC and the funds allocated for NREGS to each block. This result is consistent with a Downsian model of political opportunism. Under the Downsian model, parties are less likely to direct funds where there are very strong or where they are weak. A similar exercise is repeated for the biggest rival party - Bhartiya Janata Party (BJP). There is however no significant relationship between the vote share of BJP and funds allocated pointing out that BJP may not find it optimal or may not have the capability (key political personnel) to use strategies analogous to INC.

Our results on political opportunism imply that more funds are allocated around the mean vote share of INC (44 percent). To characterize further the political economy link, we focus on a subset of close elections over the two elections (2005 and 2010). Close elections are defined in terms of vote margins of no more than 4 percent difference between the vote share of INC (BJP) and the closest rival. ${ }^{3}$ We find that, for close elections, the relationship between INC vote share and funds is different. On an average, more funds are allocated to blocks where the vote share of INC is below the mean than above it. For example, the funds allocated to blocks where INC has a vote share of 30 percent is around 1.5 times larger than the funds allocated when the vote share is 50 percent. This

\footnotetext{
${ }^{2} \mathrm{~A}$ block is roughly the same as a panchayat samiti. We consider the set of panchayat samitis that correspond to blocks. Hence, we refer to them interchangebly in this paper.

${ }^{3} 4 \%$ is the lowest margin difference we can use for this paper due to sample size issues.
} 
can be explained by the fact that for close elections, INC targets funds to influence voters where it is weaker as compared to where it is stronger. This may be feasible within areas with close elections because voters are not necessarily biased towards any one party.

Moreover, we provide further proof that these outlays reflect political strategies by INC. The relation between vote share of INC and funds allocated is only significant when the district member of parliament (MP) is from INC. The MP is part of the district panchayat, the body that approves the block plans and is a key political personnel in the district. Interestingly, for the case of BJP, we also find a relationship similar to what we find for INC, when the MP is from BJP. This points out that, in blocks where there were close elections, BJP may have also wanted to direct NREGS funds to "buy" votes but was stymied by the lack of key personnel, since there were fewer MPs from BJP.

We also provide some suggestive evidence that the INC strategy may have been ex-post rational. Using data from 2010 elections, we show that NREGS funds had a positive effect on vote shares of INC but not of BJP.

The paper contributes to three strands of the literature: It contributes to the empirical literature on the impact of local political competition on public policy implementation. It gives further evidence that political opportunism guides how parties act on policies. After 2008, INC was in power both at the centre and the state. Hence, we are able to abstract away from any centre-state issues and focus narrowly on local elections. ${ }^{4}$ This analysis is also unique in that we consider fund flow for a policy at the block level. Similar information at this level of disaggregation for implementation of policies are tough to get, especially in developing countries. What is also useful about this exercise is that it is clear how political parties can affect outcomes, since political appointees have a declared role in fund allocation decisions.

These results are in contrast to empirical results that find evidence of political patronage in local politics (Besley et al. 2004). This paper is similar in spirit to Bardhan and Mookherjee (2010) in so far as we estimate a similar inverted U shaped relationship between political variables and the outcome. However, the differential relationship within close elections is unexplored in their analysis. These results are also in contrast to the literature that points out that pre-election transfer of funds are only useful in getting voters to election booths and not for affecting their voting choice (Cox and Kousser 1981).

The second strand of literature for which this paper is relevant is the role of local politics in affecting economic

\footnotetext{
${ }^{4}$ INC-led coalition has been in power at the centre since 2004 and formed the state government from 2008-13.
} 
outcomes. Recent work on India, by Cole (2009) and Novosad (2013), show how local elections and politicians can affect farm credit and employment respectively. Since NREGS funds affect employment rates and have also been found to have impacts on poverty (Ravi and Engler, 2009; Klonner and Oldiges 2012); by providing some evidence on how politics affect NREGS funds, our paper is indicative of a path for how politics and economic outcomes are connected.

The third strand of literature that this paper contributes to is the nascent evidence on NREGS. The scheme is one of the largest public policies in a developing country context. With an allocation of Rs. 396.54 Billion in 2012-2013 (around 6.42 Billion USD at PPP), it is bigger than PROGRESSA and has the potential to change the lives of an unprecedented number of people. Studies looking at its impact (Azam 2012, Imbert and Papp 2012) are besotted with identification issues since the intensity of the program in any area and over time is not random. In providing a political explanation for funds allocated, this paper provides a potential identification channel to examine its impact. ${ }^{5}$

In section 2, we describe the institutional setting of funds allocation across administrative units and how they are related to the local political structure. Section 3 provides description of the data. In section 4 , we lay out an empirical model and describe variables used in a multivariate panel regression model. Further, we describe our identification strategy. Section 5 describes results while section 6 offers an explanation for the results obtained. We conclude in section 7.

\section{Institutional Setting}

The National Rural Employment Guarantee Act (NREGA) provides a legal guarantee for atleast one hundred days of employment in every financial year to adult members of any rural household willing to do unskilled manual work at the notified wage. The National Rural Employment Guarantee Scheme (NREGS), which operationalized the act, started in the financial year 2005-2006 and was rolled out in phases. Initially restricted to 200 "poorest" districts of India (February 2006), it was first extended to 130 more districts in phase II (May 2007) and to all districts by 1st April 2008.

The legal entitlement of work implies that NREGS is, in principle, a demand based scheme. Thus, various

\footnotetext{
${ }^{5}$ Needless to say, this is contextual, as for many outcome variables, the exclusion criterion may not be met if political competition affects them directly.
} 
modus operandi are laid out on how demand from households is to be registered and how funds will flow through the system (Mukhopadhyay 2012). A Gram Panchayat (local government that represents a collection of villages) is responsible for identification of projects in the area under its jurisdiction (through local meetings called Gram Sabha meetings). The plans are then sent to the block level (the next higher tier). All project proposals received are integrated into the Block Plan. The Panchayat Samiti (PS), along with a block level administrative officer ( called the Program Office ${ }^{6}$ ) vets the block level plan, and forwards it to the Panchayat at the district level for final approval. A Panchayat Samiti (also referred to as an Intermediate Panchayat) is a democratically elected council, which contains members of multiple Gram Panchayats that come under it's jurisdiction. ${ }^{78}$. The District Panchayat (also an elected body, but at the district level), along with an administrative officer (usually the district collector) finalize and approve the block plans. The MP is also a member of the district panchayat and can potentially have influence on the process of approval. Based on these plans, funds are approved for Panchayat Samitis, and funds then flow to Gram Panchayats and subsequently to households that have worked on NREGS projects.

While NREGS is, in principle, a demand based scheme, there is overwhelming evidence that the scheme is top-down. Based on a village survey of 320 villages in Rajasthan, Himanshu et al. (2013) find that around 52 percent of villages believe that households only get work when there is some project available and not based on their demand. ${ }^{9}$ Moreover, Imbert and Papp (2012) report that "many people are unaware of their full set of rights under the program"; "in practice, very few job card holders formally apply for work while the majority tend to wait passively for work to be provided." Other research on Andhra Pradesh (Ravi and Engler, 2009; Afridi et al., 2013) also indicate that the program is supply rather than demand driven.

While fund allocations may not be completely demand driven, it is implausible to think that they are random. Given the various levels of local political institutions involved in the collation of demand requests, it is possible that they can influence the funds that are finally allocated. While there can be political forces at play that decide funds at the district level and at the state level, we focus, in this paper, on the intra district allocation of funds (that is, to blocks). ${ }^{10}$ Further, we look at the relationship between vote share of each party in Panchayat Samiti

\footnotetext{
${ }^{6}$ The Block Development Officer (BDO) is often appointed the program officer. The Program Officer provides preliminary approval based on verification of maintenance of 60:40 ratio of wage to materials in terms of cost.

${ }^{7}$ Most Panchayat Samitis map on perfectly to a census unit called block. A district is a collection of blocks.

${ }^{8}$ The elected heads of Gram Panchayats are also members of Panchayat Samitis. In contrast to members elected directly into the council, they have no declared party affiliation.

${ }^{9}$ This is based on a focus group discussion in each village.

${ }^{10}$ Once funds are approved for Gram Panchayats, there can be further local political forces at play. For example, Himanshu et al.
} 
elections to subsequent block level approved funds. Panchayat Samiti elections are the lowest tier of local elections, for which vote shares are recorded party wise (by the state election commission). ${ }^{11}$ In addition, we look at the influence of the MP, who is member of the district panchayat, a body that finally approves block plans. ${ }^{12}$

While other layers of politics can matter for allocation of funds under NREGS, what makes the particular context we examine useful, is that the political structure at higher tiers of governance stayed the same during the period of our study. Both the central government and the state governments were headed by the same party: INC.

\section{Data \& Descriptives}

This analysis uses data from Rajasthan, a northern state of India. Rajasthan is touted as a success story in terms of the implementation of the scheme since funds have been used to provide employment in this state, in contrast to other states of India, where its implementation has been poor. ${ }^{13}$ We seek to investigate whether NREGS fund allocation to blocks, in a financial year, depend on the existing vote share of each political party within the panchayat samiti electorate. ${ }^{14}$ We exploit the fact that elections for panchayat samitis took place in the years 2005 and 2010, which led to a change in the vote share of each party, and examine the fund allocations in the financial years 2009-2010 and 2012-2013. The choice of the years is dictated by the fact that NREGS was implemented in all districts of India (and consequently all blocks of Rajasthan) by mid-2008. Hence 2009-2010 is the first financial year for which we have data for all districts (and blocks). ${ }^{15}$ The choice of 2012-2013 was dictated by the fact, that given the complicated machinery of NREGS, it is plausible that it would take time for the newly elected local politicians to learn about how NREGS funding works. Indeed, 2010-2011 showed a sharp dip in total NREGS

(2013) find, that in multi-village Gram panchayats, the village of the head of the Gram Panchayat (called the Sarpanch) gets more NREGS work.

${ }^{11}$ These elections are the lowest tier where candidates can declare parties. While elected leaders at lower levels of governance (head of Gram Panchayats) often have party affiliations, these are informal and never officially declared.

${ }^{12}$ We do not look at the party composition of the district panchayat since the members are elected at the same time as the panchayat samiti members. The MP is elected through a national election which was held earlier.

${ }^{13}$ The total funds for Rajasthan for the years 2009 and 2012 were Rs. 82027.25 million and Rs 37757.78 million respectively. The state government, in many press releases, has claimed that there is decreasing demand for NREGS which needs to be investigated. The drop in over all funds for NREGS in Rajasthan has also been noted by Mukhopadhyay (2012).

${ }^{14} \mathrm{We}$ choose to look at fund allocations instead of expenditures because the latter is subject to issues of corruption and village politics, issues which are not relevant for testing our hypothesis.

${ }^{15}$ It may be argued that results are affected by the inclusion of the election year. The choice of 2009 is dictated by the spread of the program. By 2009, all the districts (and blocks) had NREGS running in full swing. A previous year would have meant this allocation would be zero for many districts and blocks which were dealing with the scheme for the first time. Moreove,r the national elections were held in early 2009. Hence 2008-09 allocations is likely to be equally distorted by the national elections. 
funds for the state. We also consider 2012-2013 so as to ensure that the unspent balances from previous years that often get extended to the funds available in the next financial year belong to the same political regime (post 2010). Our results stay the same even if we look at fund allocations in 2011-2012.

The block level approved funds for NREGS for a financial year include fresh funds sanctioned as well as outstanding balance from the previous year ${ }^{16}$. Data on these are sourced from the official website of the Government of India. ${ }^{17}$ The data are obtained for 219 blocks for financial years 2009-2010 and 2012-2013 (for ease of presentation, we refer to them as 2009 and 2012 respectively). ${ }^{18}$ The average block level funds for Rajasthan for the years 2009 and 2012 were Rs. 173.36 million and Rs 108.04 million respectively (Table 1.A).

The data on vote share for each party are obtained from the state election commission website ${ }^{19}$. Data are obtained on panchayat samiti elections held in 2005 and 2010. Each panchayat samiti is divided into wards and members are elected from each ward. The number of wards in each panchayat samiti vary depending on population. While the total number of votes for each party from each ward are not reported, the over all votes for each party for the entire panchayat samiti are recorded. ${ }^{20}$ We divide the votes a party gets by the total number of votes cast to calculate a party's vote share. Rajasthan politics is dominated by two main national parties of India: the Indian National Congress (INC) and Bharatiya Janata Party (BJP). The average vote share of INC in 2005 was 41.1 percent while it increased to 42.3 percent in 2010. The BJP's vote share decreased from 40.3 percent in 2005 to 36.7 percent in 2010. The two vote shares together account for around 80 percent of the votes. Figures 1 and 2 show the spatial distribution of INC vote share across the state for the election years 2005 and 2010 respectively. As can be seen, there is fair heterogeneity in vote share for both years. It is also important for our analysis that even within a district, there is fair degree of heterogeneity across blocks in vote share. The striped portions reflect blocks where the INC vote margin was less than equal to 4 percent. As can be gleaned from the figures, close elections are not concentrated in any particular region. A comparison of Figures 1 and 2 also shows that the vote shares have temporal variation. ${ }^{21}$

The block level funds are matched to panchayat samiti vote shares. As noted before, we are able to match

\footnotetext{
${ }^{16}$ The proportion of Outstanding balance to total funds was 0.22 and 0.19 for the years 2009 and 2012 respectively.

${ }^{17}$ http://nrega.nic.in/netnrega/home.aspx

${ }^{18}$ There are 248 blocks in total. We drop blocks which could not be mapped onto panchayati samitis, the area delimited for election purposes.

${ }^{19} \mathrm{http}: / /$ www.rajsec.rajasthan.gov.in

${ }^{20}$ The Panchayat Samiti is, anyways, the level of aggregation relevant for block level funds.

${ }^{21} \mathrm{INC}$ is relatively weaker in the north eastern blocks. However, even there, there is intra district variation in vote shares of INC.
} 
these perfectly for 219 blocks and use this subsample for our analysis. The unconditional correlation between INC vote share and funds, after pooling the data for the two years, is 0.28 while that for BJP vote share and funds is much weaker at 0.13 . However, these correlations could also be driven by other factors: those that affect the household demand for work. Intra-district analysis alleviates some of these concerns. The presence of confounding factors, however requires that we model the correlation between funds and vote share in a multivariate framework. The data on demographic variables are sourced from Census 2001 and 2011. Rainfall data is available only at the district level and is sourced from the Indian Meteorological Department. The descriptive statistics for these variables are summarized in Table 1.A for all panchayat samitis and in Table 1.B for panchayat samitis that had close elections.

\section{Empirical Model and Identification}

Our main hypothesis is that, controlling for other factors that affect demand for funds, political competition has a role to play in fund allocations across blocks. In particular, we test what the nature of this role is. It is not clear apriori what the relation should be. For example, models of patronage imply that funds should be transferred, where it is possible to do so, to where the vote bank of parties are. Alternatively, it may be optimal, in some contexts, to transfer funds to swing areas where the marginal impact of fund transfers on votes is the highest. In other contexts still, greater funds may be transferred (if such transfer is possible) to constituencies where a party is weakest if vote buying is cheap and funds are not constrained. Bardhan and Mookherjee (2010) layout models that generate some of these alternate hypotheses.

We focus, in particular, on INC in Rajasthan and its share of votes in panchayat samiti elections. To fix ideas, let $p$ stand for the panchayat samiti/block; let $d$ refer to the district where $p$ is situated. The dependent variable in this analysis is the $\log$ of funds $\left(L n \_f u n d s_{p d t}\right)$; where $t$ takes the value 0 for the year 2009 and 1 for 2012 . In our main regression, we take the vote share of INC in a panchayat samiti as our main political economy variable $\left(I N C \_\right.$voteshare $\left.e_{p d t}\right)$. Since votes shares of all parties within a panchayat samiti add up to 100, the marginal effect of INC_voteshare measures the impact of a higher share of INC relative to other parties, including the BJP. In line with Bardhan \& Mookherjee (2010), we allow for non linearity by considering, in addition to the linear term,

a quadratic term $\left(I N C_{-}\right.$voteshare $\left.p_{p d t}^{2}\right)$. Further, the number of wards in a panchayat samiti wards $s_{p d t}$ may reflect 
the level of competition in a block. While the number of wards are typically a function of population, the number of wards vary over time though the demarcation of panchayat samitis did not change.

To eliminate the impact of demand on NREGS funds, we control for variables that may affect the demand. We posit that the demand for NREGS funds depends on rainfall shock (rain_dev $d t)$ as NREGS has been put in place to mitigate effects of droughts. Moreover, funds allocated may depend on the population of a block $p o p_{p d t}$. One would expect more funds would be allocated to areas where there was a higher proportion of the relatively less prosperous communities. Hence the proportion of Scheduled Castes $\left(S C_{p d t}\right)$ and Scheduled Tribes $\left(S T_{p d t}\right)$ in the block are included as control variables. Moreover, the labor force participation of women in NREGS has been huge in Rajasthan. Hence we include the proportion of females in the population $\left(f_{e} m_{p d t}\right)$ as a explanatory variable. Further, to measure underdevelopment at the block level, which may lead to a higher NREGS demand, we take into account the illiteracy rate $I L L_{p d t}$.

To alleviate concerns that unobserved variables may influence fund allocations, we include panchayat samiti dummy variables $\left(\delta_{p d}\right)$ to take into account panchayat samiti idiosyncrasies, for example, its geographic location. Moreover, we allow for a secular trend $\left(\delta_{t}\right)$ to take into account falling funds for NREGS in Rajasthan. We also include district trends $\left(\rho_{d t}\right)$ over the period to take into account trends in alternative employment opportunities (wages) at the district level. In addition we allow for a trend that depends on a development index for a block $\left(\operatorname{Infra} a_{p d 0}\right)^{22}$ and another trend that depends on the amount of irrigated land within a block $\left(\operatorname{Irr}_{p d 0}\right)$. Both these variables are measured in 2001 and reflect base values. ${ }^{23}$. Hence the empirical model we estimate is:

$$
\begin{aligned}
\text { Ln_funds }_{p d t}= & \alpha+\delta_{t}+\delta_{p d}+\rho_{d t}+\rho_{1} \operatorname{Irr}_{p d 0} * t+\rho_{2} \text { Infra }_{p d 0} * t+ \\
& +\beta_{1} I N C_{-} \text {voteshare } \\
& +\beta_{3} \text { ward }+\beta_{2} I N s_{p d t}+\mu^{\prime} Z_{p d t}+\varepsilon_{p d t}
\end{aligned}
$$

where $Z$ is a vector that includes all the other control variables.

To estimate this model, we use a balanced panel of blocks and apply a fixed effects estimator. This eliminates

\footnotetext{
${ }^{22}$ In $f r a_{p d 0}$ is created using principle component analysis taking into account Average No of Schools per village, Proportion of Villages with power supply, Proportion of villages with a medical facility.

${ }^{23}$ The data for these variables are sourced from 2001 census. Similar data are not available currently for the 2011 census at the block level.
} 
the panchayat samiti time invariant idiosyncrasies. It also eliminates rainfall shock, as that is measured at the district level, and is therefore collinear with the district trend. The district trend also eliminates the need to include district funds as a variable. We are then interested in examining the sign and statistical significance of $\beta_{1}, \beta_{2}$ and $\beta_{3}$.

It may be contended that vote shares may themselves be affected by funds. While this is unlikely for 2005 election (NREGS was not around), it is plausible that funds allocated in 2009-10 affect election outcomes in

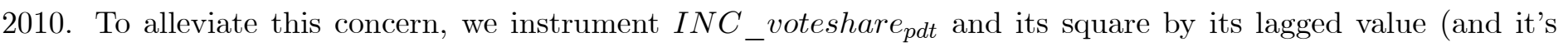
square). Our identification assumption therefore is that 2005 election results affect 2010 election results but have no further effect on the funds allocated in 2012. Similarly, vote shares in 2000 affect vote shares in 2005 but have no subsequent impact on the funds allocated in 2009. The raw correlation between vote shares and their lag is 0.758 in the case of INC and 0.706 for BJP. ${ }^{24}$

Next we look at close elections. The dynamics of close elections may be very different to the over all elections. Voters in close elections are less likely to be biased towards one party than the other and hence it may be more plausible that funds may be used to influence voters. Hence the correlation between vote shares and funds may be different to the overall result. We define a close election for INC as one where INC won or lost by a margin of less than 4 percentage points. The sample of close elections is however unbalanced and it is not practical to run fixed effects models on a balanced panel. ${ }^{25}$. We therefore estimate this model using a random effects model. In this formulation, we do not instrument the variables since the actual proportion for INC (and BJP) can be taken to quasi-random. However, it is possible that the probability of a panchayat samiti having a close election is a function of funds (in particular for 2010 elections) which would lead to a sample selection bias. To show that this is not the case, for 2010, we run a probit model where the dependent variable takes the value 1 if the panchayat samiti had close elections and 0 otherwise. After controlling for all the confounding factors, we test whether funds in 2009 affect the probability of close elections.

Analogous to the above specifications with $I N C$, we estimate models where the $I N C$ _voteshare is replaced by $B J P_{\text {_ }}$ voteshare. To maintain comparability, close elections are defined in terms of victory and loss margins

\footnotetext{
${ }^{24}$ The BJP and INC compete for all Panchayat Samiti elections in 2005 and 2010. However, in the 2000 elections, there are some panchayat samitis that they do not figure in. It is therefore likely that INC and BJP entered into pre poll alliances with some parties/independents and therefore it would be incorrect to assume that the vote share for them is zero. We drop these panchayat samitis in our 2 SLS regressions and hence our sample size drops to 213 for INC and 205 for BJP.

${ }^{25} \mathrm{~A}$ balanced panel would leave us with only 62 observations.
} 
for $B J P$.

Next, we test the hypothesis if key political appointees matter for funds sanction within close elections. We focus on the district panchayat, which finally approves block plans. The MP is a member of the district panchayat which, together with the administrative officer, approves block level fund allocations. We construct a variable: $I N C_{-} M P$ which takes the value 1 if the district $\mathrm{MP}$ is from $I N C, 0$ otherwise. ${ }^{26}$ Thus, we modify equation (1) to include this variable by interacting it with the linear and quadratic terms of $I N C \_v o t e s h a r e^{27}$. Thus:

$$
\begin{aligned}
\text { Ln_funds }_{p d t}= & \alpha+\delta_{t}+\delta_{p d}+\rho_{d t}+\rho_{1} \operatorname{Irr}_{p d 0} * t+\rho_{2} \text { Infra }_{p d 0} * t+ \\
& +\beta_{1} I N C_{-} \text {voteshare }{ }_{p d t}+\beta_{2} I N C_{-} \text {voteshare }_{p d t}^{2} \\
& +\beta_{3} \text { wards }_{p d t}+\beta_{4} I N C_{-} \text {voteshare }_{p d t} * I N C_{-} M P_{d}+ \\
& +\beta_{5} I N C_{-} \text {voteshare }{ }_{p d t}^{2} * I N C_{-} M P_{d}+ \\
& +\mu^{\prime} Z_{p d t}+\varepsilon_{p d t}
\end{aligned}
$$

We estimate a similar regression for $B J P_{-} M P$.

Standard errors reported are robust and are clustered at the block level. ${ }^{28}$

\section{Results}

To begin with, we present results from a pooled OLS regression with and without district trend ( Table 2; Columns 2 and 1 ). Block level fund allocations for NREGS are clearly a function of political variables (Table 2). Though the coefficient of INC_voteshare and its square are positive but insignificant, the marginal effects are positive and significant above a vote share of 22 percent for both specifications. However, the coefficients start changing sign as soon as we account for unobserved panchayat samiti-level heterogeneity. In column (3), we report results after we control for Panchayat samiti fixed effects. The negative coefficient on INC_voteshare implies that larger

\footnotetext{
${ }^{26}$ Anecdotally, it would seem that the pradhan (head of the panchayat samiti) and the head of the district panchayat are also important in getting higher funds for a block. However, the elections for the district and panchayat samiti take place at the same time and the heads are chosen within the elected members. Hence we look at the district MP, who was elected at the beginning of 2009 via national elections for a period of 5 years.

${ }^{27}$ The variable, in its uninteracted form, is collinear with the district trend.

${ }^{28}$ Results do not change if we cluster at the district level.
} 
funds are available where the vote share of INC in the panchayat samiti constituency (block) is low. While the square term is positive (though insignificant), a marginal effects calculation yields the result that the marginal

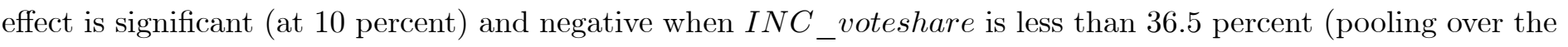
two years, this forms around 25 percent of the sample). This implies higher funds are available in places where INC has very low vote share from previous elections. The coefficient of total number of wards in a panchayati samiti (wards) is positive and significant. However, as we have pointed out above, these results may be biased. Hence we instrument $I N C_{-}$voteshare and it's square by it's lagged value and it's square. This yields a inverted $\mathrm{U}$ shape for the effect of INC vote share on funds (column 3). ${ }^{29}$ The linear term is positive and significant while the quadratic term is negative and significant. To understand the implication of these coefficients on funds, let us fix as a benchmark, the average funds when the $I N C_{-}$voteshare is 64 percent and above (at which point the marginal effect becomes insignificant). Now, we calculate the funds at other levels of vote shares, as a proportion of this benchmark. This proportion reaches a maximum at around 35 percent where it almost 5 times higher than the benchmark ( Figure 3).

To identify the impact of other variables, it is perhaps more intuitive to look at columns (1 and 2$)$ since in other specifications, the use of intra district variation renders most variables insignificant. The results in columns 1 and 2 are largely consistent in sign, though the inclusion of district trends renders some variables insignificant. Blocks in districts with better rainfall shock received lesser funds. Blocks with higher amount of land irrigated (in 2001) received lesser funds. A similar result is obtained when we look at the infrastructure index and funds. Blocks with higher infrastructure receive lesser funds and this is especially true in 2012. Areas with higher Schedule Caste and Schedule Tribe communities in Rajasthan receive higher funds. NREGS funds are higher where there are more women. Given the large participation of women in NREGS program in Rajasthan, this is plausible. The results on the proportion of illiterates are similar: significant and positive in the pooled cross section.

Next we ask if the results change if we replace $I N C$ by $B J P$. In the cross sectional regression (Table 3; Columns 1 and 2), the coefficients of $B J P_{-}$voteshare on funds is insignificant though the marginal effect is significant above $22 \%$. However as soon as we move to any specification with fixed effects and trends, the marginal effect is insignificant at any value of BJP vote share.(Table 3 and Appendix Table 2).

\footnotetext{
${ }^{29}$ The first stage results are reported in Appendix Table A1. While the lagged INC vote share and it's square are insignificant, they are jointly significant at $5 \%$. The $\mathrm{F}$ stat of the equations are 21.01 and 19.28 respectively.
} 
As argued above, close elections may have different dynamics. ${ }^{30}$ Hence, as discussed above, we run a random effects specification for close elections. To begin with we run a probit model where the dependent variable takes the value 1 if in 2010, the panchayat samiti election was close and 0 otherwise. The covariates considered are the same as in earlier regressions but for $t=0$. Marginal effects reported in Appendix Table A3 show that the funds in 2009 do not affect the probability of close elections in 2010. Hence our sample, atleast for 2010, is unlikely to suffer from a selection bias. This test is not relevant for 2005 as NREGS started later. The relationship between INC_voteshare and funds has a different shape once we look at close seats (Table 4: Column 1). The linear term is now negative while the quadratic term is positive implying a downward sloping convex shape. If we fix the benchmark funds as the average funds at 44 percent, the funds at around 30 percent are almost 3 times larger than the benchmark (Figure 4). ${ }^{31}$ Even at 35 percent, the funds are almost 1.4 times higher. While the funds have a U shaped relationship, with greater funds at 50 percent than the benchmark, the proportion at 50 percent vote share is around 1.5 percent, much less than the proportion at 30 percent vote share. This points out to both vote buying (at the lower end) as well as patronage (at the higher end) within close seats. A similar exercise for BJP gives no significant results (Table 4: Column 3).

To investigate this further, we delve deeper into a mechanism that may drive this result. For this, we look at the results from estimating equation (3). Recall that, we seek to test whether INC are able to implement their strategies depends on whether the district MP, a key political personnel, who is also responsive for approving block level plans, is from INC. Table 4 (Column 2) reports the results while Table 5 reports the marginal effects. It is clear to see that when the MP is not from INC, the coefficients of INC_voteshare and its square are always insignificant. The implied marginal effects are also insignificant at all values of INC_voteshare (Table 5). However, when the district head is from INC, the marginal effects of INC_voteshare are similar to what is obtained above: they are negative and significant. As Figure 5 shows, the effects are exaggerated when the MP is from INC as compared to the over all effects (that is denoted by the dashed line). Now the funds are almost 4 times higher when the vote share is 30 percent. The patronage is also higher with the funds at 50 percent almost twice as compared to benchmark funds.

Interestingly, in the case of BJP we observe a similar shape when the district MP is from the BJP. The

\footnotetext{
${ }^{30}$ Similar concerns have often being raised when RDD methods are applied to political economy problems.

${ }^{31}$ The choice of the range 30 to 50 is based on the empirical vote share for close seats.
} 
negative relation between vote share and funds are significant between 38 and 42 percent vote share for BJP. However, like INC, the relationship is insignificant when the MP is not from BJP.

\section{Discussion of Results}

In the previous section we find two kinds of results: those for all seats and those for close elections. The results for all the seats echoes the results obtained by Bardhan and Mookherjee (2010) in the context of land reforms in West Bengal. Clearly, if a party is very weak in a particular area or very strong, a party may not find it optimal to influence fund allocations to those areas. Instead it may aim to deliver funds towards areas where the polity does not take extreme ideological positions. These results can be motivated through a quasi-Downsian model as postulated by Bardhan and Mookherjee (2010). However, our second result points out that within areas with close elections (that is, a subset of areas where polity does not take extreme ideological positions), the correlations may be different. It may be beneficial to transfer higher funds to where it got more than average vote share, as a reward to people who voted for it in close elections. But there is also a component of vote buying by transferring funds to where it got less than average votes. Recall that these are close seats; hence it is not prohibitively costly to "buy" these votes. This is in contrast to over all results where it may be too costly to influence voters where vote shares are very low. This suggests that the fund allocation is influenced by INC political objectives.

To examine this further, we focus on whether the implied strategy by INC was ex-post effective. Hence we investigate whether, in 2009, the fund allocations to blocks where INC had low vote share helped them increase their vote share in 2010 elections. For this, we run a cross sectional regression (with district fixed effects) where the dependent variable is the vote share of INC in 2010 divided by the vote share of INC in $2005\left(\right.$ prop $\left._{p d}\right)$. We estimate the following regression:

$$
\operatorname{prop}_{p d}=\alpha+\rho_{d}+\beta_{1} \text { Fund }_{p d 0}+\beta_{2} F u n d s_{p d 0} * I N C_{-} \text {voteshare }{ }_{p d 0}+\mu^{\prime} Z_{p d 0}+\varepsilon_{p d 0}
$$

where 0 refers to the period before the 2010 election. Since the regression allows for district fixed effects $\left(\rho_{d}\right)$,we investigate if within a district, higher funds to a block leads to higher value of prop $p_{p d}$. Moreover, we allow the marginal effect of funds to depend on the initial vote share $I N C_{-}$voteshare $_{p d 0}$. The results $($ Table 6 ; column (1)) 
indicate that higher block funds lead to a larger increase in vote share in 2010 elections relative to the previous election. Moreover the effect of funds is largest when the $I N C_{-} v_{\text {voteshare }}$ pd 0 is lower. One standard deviation

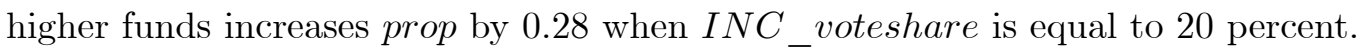

To complete the narrative, one needs to reconcile why we don't observe results similar to $I N C$ for $B J P$. As has been suggested, there are two reasons why we might not see results for the rival party. First, it may not be optimal for BJP to use funds from NREGS since it is primarily thought of us as a central government scheme. Hence there may be leakage of goodwill that defeats the purpose of using these funds to influence voters. Second, even if BJP may want to allocate funds according to a strategy similar to INC, it may not be able to do so unless there is alignment of interest. In particular, the result that marginal effects are only significant when the MP is from BJP suggests that having key personnel is an important part of the story. This point is echoed even in the case of INC where the marginal effects are only significant when the MP is from INC.

The result that we do not observe any result when we focus on BJP is again borne out when we test for the ex post effect of funds on BJP vote share. The coefficient is insignificant.

\section{Conclusion}

In this paper, we provide evidence on how political competition affects implementation of policies. We use the particular context of the National Rural Employment Guarantee Scheme (NREGS) in Rajasthan, a state in India. This scheme was introduced by the Indian National Congress(INC). Using panel data techniques and instrumenting for endogenous vote share by its lagged value, we show that the relationship at the block level, between vote share of INC in elections and the subsequent fund allocations is concave (inverted U shaped). In contrast, funds are invariant to the vote shares of the biggest rival party. Results however, differ when we consider close elections, that is, the sample of blocks, where INC won or lost closely. We find that though there is some evidence of patronage, larger funds were sanctioned in areas with relatively lower vote shares . We offer alternate explanations for these results in terms of incentives of parties to implement the scheme, as well as, the capacity to be able to do so. In doing so, this paper points out to the potential problems of implementing public work schemes through a decentralized mechanism which involves political players. 


\section{References}

[1] Afridi, F., Iversen, V., and Sharan, M. R. (2013). Women Political Leaders, Corruption and Learning: Evidence from a Large Public Program in India. IZA Discussion Paper No. 7212.

[2] Arulampalam, W., Dasgupta, S., Dhillon, A., and Dutta, B. (2009). Electoral goals and center-state transfers: A theoretical model and empirical evidence from India. Journal of Development Economics, 88(1), 103-119.

[3] Azam, M. (2012). The Impact of Indian Job Guarantee Scheme on Labor Market Outcomes: Evidence from a Natural Experiment, IZA Discussion Paper No. 6548

[4] Bardhan, P., and Mookherjee, D. (2000). Capture and governance at local and national levels. The American Economic Review, 90(2), 135-139.

[5] Bardhan, P., and Mookherjee, D. (2010). Determinants of redistributive politics: An empirical analysis of land reforms in West Bengal, India. The American Economic Review, 1572-1600.

[6] Besley, T., and Coate, S. (1997). An economic model of representative democracy. The Quarterly Journal of Economics, 112(1), 85-114

[7] Besley, T., Pande, R., Rahman, L. and Rao, V. (2004), The politics of public goods provision: Evidence from Indian local governments. Journal of the European Economic Association, 2(2-3), 416-426

[8] Cox, Gary W. and Kousser, J. Morgan (1981) Turnout and Rural Corruption: New York as a Test Case. American Journal of Political Science, 25 (4), 646-663

[9] Cole, S. (2009). Fixing market failures or fixing elections? Agricultural credit in India. American Economic Journal: Applied Economics, 219-250.

[10] Himanshu, Mukhopadhyay, A., and Sharan, M. (2013). The Dynamics of NREGS fund allocations in Multi Village Panchayats: Evidence from Rajasthan, Mimeo.

[11] Imbert, C., and Papp, J. (2012). Equilibrium Distributional Impacts of Government. Employment Programs: Evidence from India's Employment Guarantee, Paris School of Economics Working Paper 2012-14. 
[12] Klonner, S., and Oldiges, C. (2012). Employment Guarantee and its Welfare Effects in India, Working Paper, University of Heidelberg.

[13] Mukhopadhyay, A. (2012). The Political Economy of Implementing the National Rural Employment Guarantee Scheme in India, ESID Working Paper No. 15, September 2012

[14] Novosad, P. and Asher, S. (2013). Politics and Local Economic Growth: Evidence from India, Mimeo

[15] Ravi, S., and Engler, M. (2009). Workfare in Low income Countries: An effective Way to Fight Poverty? The Case of NREGS in India, Indian School of Business Working Paper. 


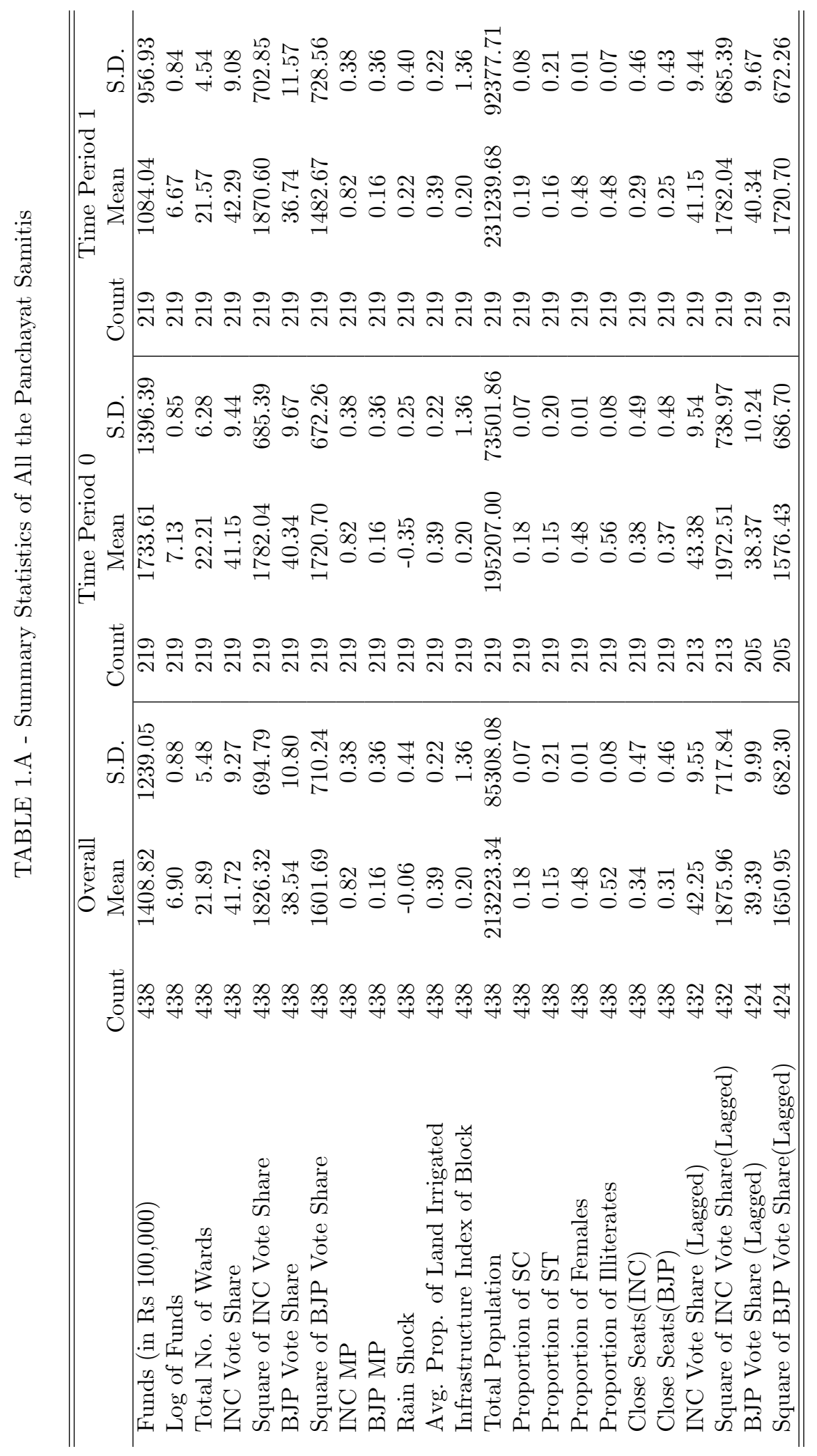


TABLE 1.B - Summary Statistics of Close Election Panchayat Samitis

\begin{tabular}{lccc|ccc}
\hline \hline & \multicolumn{3}{c}{ Overall- INC } & \multicolumn{3}{c}{ Overall- BJP } \\
& Count & Mean & S.D. & Count & Mean & S.D. \\
\hline Funds (In Rs. 100,000) & 147 & 1340.32 & 1054.30 & 136 & 1372.41 & 1064.76 \\
Log of Funds & 147 & 6.93 & 0.79 & 136 & 6.97 & 0.74 \\
Total No. of Wards & 147 & 21.28 & 5.21 & 136 & 21.17 & 4.99 \\
INC Vote Share & 147 & 43.09 & 4.83 & 136 & 43.25 & 5.24 \\
Square of INC Vote Share & 147 & 1880.03 & 405.29 & 136 & 1897.74 & 422.11 \\
BJP Vote Share & 147 & 41.54 & 8.18 & 136 & 43.41 & 4.90 \\
Square of BJP Vote Share & 147 & 1792.38 & 562.22 & 136 & 1908.38 & 406.15 \\
INC MP & 147 & 0.73 & 0.44 & 136 & 0.73 & 0.45 \\
BJP MP & 147 & 0.22 & 0.42 & 136 & 0.24 & 0.43 \\
Rain Shock & 147 & -0.16 & 0.39 & 136 & -0.20 & 0.37 \\
Avg. Prop. of Land Irrigated & 147 & 0.43 & 0.23 & 136 & 0.42 & 0.23 \\
Infrastructure Index of Block & 147 & 0.12 & 1.32 & 136 & 0.10 & 1.35 \\
Total Population & 147 & 193418.03 & 75736.46 & 136 & 188816.88 & 71471.64 \\
Proportion of SC & 147 & 0.20 & 0.07 & 136 & 0.20 & 0.06 \\
Proportion of ST & 147 & 0.12 & 0.14 & 136 & 0.12 & 0.12 \\
Proportion of Females & 147 & 0.48 & 0.01 & 136 & 0.48 & 0.01 \\
Proportion of Illiterates & 147 & 0.52 & 0.08 & 136 & 0.52 & 0.08 \\
INC Vote Share (Lagged) & 146 & 43.75 & 6.72 & 135 & 44.25 & 6.28 \\
Square of INC Vote Share(Lagged) & 146 & 1958.81 & 562.01 & 135 & 1997.05 & 532.64 \\
BJP Vote Share (Lagged) & 144 & 41.23 & 8.10 & 134 & 42.24 & 7.09 \\
Square of BJP Vote Share(Lagged) & 144 & 1764.71 & 574.44 & 134 & 1834.13 & 519.47 \\
\hline \hline
\end{tabular}


TABLE 2- All the Panchayat Samitis

\begin{tabular}{|c|c|c|c|c|}
\hline Dependent variable: Log of Funds & $\begin{array}{c}(1) \\
\text { INC-OLS }\end{array}$ & $\begin{array}{c}(2) \\
\text { INC-OLS }\end{array}$ & $\begin{array}{c}(3) \\
\text { INC-FE }\end{array}$ & $\begin{array}{c}(4) \\
\text { INC- } \mathrm{FE}(2 \mathrm{SLS}) \\
\end{array}$ \\
\hline INC Vote Share & $\begin{array}{c}0.0110 \\
(0.0196)\end{array}$ & $\begin{array}{c}0.0157 \\
(0.0177)\end{array}$ & $\begin{array}{c}-0.0263^{* *} \\
(0.0132)\end{array}$ & $\begin{array}{c}0.146^{*} \\
(0.0850)\end{array}$ \\
\hline Square of INC Vote Share & $\begin{array}{c}0.000143 \\
(0.000264)\end{array}$ & $\begin{array}{c}2.25 \mathrm{e}-05 \\
(0.000239)\end{array}$ & $\begin{array}{c}0.000229 \\
(0.000192)\end{array}$ & $\begin{array}{c}-0.00206^{*} \\
(0.00108)\end{array}$ \\
\hline Total Number of Wards & $\begin{array}{c}0.0515^{* * *} \\
(0.00984)\end{array}$ & $\begin{array}{c}0.0471^{* * *} \\
(0.00859)\end{array}$ & $\begin{array}{c}0.0350^{* * * *} \\
(0.0111)\end{array}$ & $\begin{array}{c}0.0363^{* * *} \\
(0.00963)\end{array}$ \\
\hline Proportion of land irrigated(2001) & $\begin{array}{c}-0.490^{* *} \\
(0.226)\end{array}$ & $\begin{array}{c}-0.528^{* *} \\
(0.241)\end{array}$ & & \\
\hline Proportion of land irrigated $(2001) *$ Trend & $\begin{array}{l}0.0669 \\
(0.241)\end{array}$ & $\begin{array}{c}0.749^{* *} \\
(0.307)\end{array}$ & $\begin{array}{c}0.310 \\
(0.251)\end{array}$ & $\begin{array}{c}0.473 \\
(0.320)\end{array}$ \\
\hline Infrastructure Index (2001) & $\begin{array}{l}-0.0348 \\
(0.0414)\end{array}$ & $\begin{array}{c}0.000593 \\
(0.0404)\end{array}$ & & \\
\hline Infrastructure Index (2001) *Trend & $\begin{array}{c}-0.0974^{* *} \\
(0.0422)\end{array}$ & $\begin{array}{l}-0.0671 \\
(0.0488)\end{array}$ & $\begin{array}{c}-0.103^{* *} \\
(0.0431)\end{array}$ & $\begin{array}{l}-0.113^{* *} \\
(0.0551)\end{array}$ \\
\hline Total Population & $\begin{array}{c}6.05 \mathrm{e}-07 \\
(5.55 \mathrm{e}-07)\end{array}$ & $\begin{array}{c}1.58 \mathrm{e}-07 \\
(5.24 \mathrm{e}-07)\end{array}$ & $\begin{array}{l}-6.34 \mathrm{e}-07 \\
(1.55 \mathrm{e}-06)\end{array}$ & $\begin{array}{c}1.37 \mathrm{e}-06 \\
(2.05 \mathrm{e}-06)\end{array}$ \\
\hline Proportion of Scheduled Caste individuals & $\begin{array}{c}2.197^{* * *} \\
(0.814)\end{array}$ & $\begin{array}{c}1.828^{* *} \\
(0.841)\end{array}$ & $\begin{array}{l}-8.758 \\
(5.447)\end{array}$ & $\begin{array}{l}-5.404 \\
(5.237)\end{array}$ \\
\hline Proportion of Scheduled Tribe individuals & $\begin{array}{c}0.978^{* * *} \\
(0.311)\end{array}$ & $\begin{array}{c}0.822^{* * *} \\
(0.298)\end{array}$ & $\begin{array}{c}0.384 \\
(1.321)\end{array}$ & $\begin{array}{c}2.047 \\
(1.633)\end{array}$ \\
\hline Proportion of Females & $\begin{array}{l}7.102^{*} \\
(4.037)\end{array}$ & $\begin{array}{l}7.727^{*} \\
(4.234)\end{array}$ & $\begin{array}{l}2.948 \\
(7.664)\end{array}$ & $\begin{array}{l}6.189 \\
(9.111)\end{array}$ \\
\hline Proportion of Illiterates & $\begin{array}{c}1.715^{* * *} \\
(0.700)\end{array}$ & $\begin{array}{c}2.432^{* * *} \\
(0.587)\end{array}$ & $\begin{array}{l}1.058 \\
(1.599)\end{array}$ & $\begin{array}{l}-1.379 \\
(2.059)\end{array}$ \\
\hline Rain Shock & $\begin{array}{c}-0.372^{* * *} \\
(0.126)\end{array}$ & & & \\
\hline Time Trend & $\begin{array}{l}-0.180 \\
(0.134)\end{array}$ & $\begin{array}{c}-0.467^{* *} \\
(0.182)\end{array}$ & $\begin{array}{c}1.151^{* * *} \\
(0.264)\end{array}$ & $\begin{array}{c}0.988^{* * *} \\
(0.294)\end{array}$ \\
\hline Constant & $\begin{array}{c}0.306 \\
(1.950)\end{array}$ & $\begin{array}{l}0.0428 \\
(2.025)\end{array}$ & $\begin{array}{c}6.666 \\
(4.155)\end{array}$ & \\
\hline Panchayat Samiti Fixed Effects & No & No & Yes & Yes \\
\hline District Trend & No & Yes & Yes & Yes \\
\hline Time Trend & Yes & Yes & Yes & Yes \\
\hline Observations & 438 & 438 & 438 & $426^{\#}$ \\
\hline R-squared & 0.430 & 0.604 & 0.753 & 0.659 \\
\hline Number of id & & & 219 & 213 \\
\hline
\end{tabular}

Robust Std.Errors( in parentheses) are clustered at Panchayat Samiti $* * * \mathrm{p}<0.01, * * \mathrm{p}<0.05, * \mathrm{p}<0.1$

\# See Footnote No. 24 
TABLE 3 - All the Panchayat Samitis

\begin{tabular}{lcccc}
\hline \hline & $(1)$ & $(2)$ & $(3)$ & $(4)$ \\
Dependent variable: Log of Funds & BJP-OLS & BJP-OLS & BJP-FE & BJP-FE(2SLS) \\
\hline & & & & \\
BJP Vote Share & -0.000528 & .0111544 & -0.00638 & 0.0310 \\
& $(0.0116)$ & $(.0124812)$ & $(0.0143)$ & $(0.0767)$ \\
Square of BJP Vote Share & 0.000204 & .0000465 & 0.000177 & $3.90 \mathrm{e}-05$ \\
& $(0.000201)$ & $(.0002011)$ & $(0.000224)$ & $(0.000739)$ \\
& & & & \\
Other Controls & No & No & Yes in Table2) & Yes \\
Panchayat Samiti Fixed Effects & No & Yes & Yes & Yes \\
District Trend & Yes & Yes & Yes & Yes \\
Time trend & & & & \\
& 438 & 438 & 438 & $410^{\#}$ \\
Observations & 0.413 & 0.601 & 0.750 & 0.741 \\
R-squared & & & 219 & 205 \\
Number of id & \multicolumn{4}{c}{}
\end{tabular}

Robust Std. Errors( in parentheses) clustered at Panchayat Samiti level $* * * \mathrm{p}<0.01,{ }^{*} * \mathrm{p}<0.05,{ }^{*} \mathrm{p}<0.1$

\# See Footnote No. 24 
TABLE 4 - Close Election Panchayat Samitis

\begin{tabular}{|c|c|c|c|c|}
\hline Dependent Variable:Log of Funds & $\begin{array}{c}(1) \\
\text { INC- RE }\end{array}$ & $\begin{array}{c}(2) \\
\text { INC- RE }\end{array}$ & $\begin{array}{c}(3) \\
\text { BJP- RE }\end{array}$ & $\begin{array}{c}(4) \\
\text { BJP- RE }\end{array}$ \\
\hline INC Vote Share & $\begin{array}{c}-0.675^{* *} \\
(0.267)\end{array}$ & $\begin{array}{c}-0.116 \\
(0.400)\end{array}$ & & \\
\hline Square of INC Vote Share & $\begin{array}{c}0.00810^{* *} \\
(0.00320)\end{array}$ & $\begin{array}{c}0.00124 \\
(0.00452)\end{array}$ & & \\
\hline INC MP*INC Vote Share & & $\begin{array}{c}-0.759^{*} \\
(0.460)\end{array}$ & & \\
\hline INC MP*Square of INC Vote Share & & $\begin{array}{l}0.00931^{*} \\
(0.00526)\end{array}$ & & \\
\hline BJP Vote Share & & & $\begin{array}{c}0.106 \\
(0.163)\end{array}$ & $\begin{array}{c}0.00914 \\
(0.242)\end{array}$ \\
\hline Square of BJP Vote Share & & & $\begin{array}{c}-0.000646 \\
(0.00192)\end{array}$ & $\begin{array}{c}0.000187 \\
(0.00283)\end{array}$ \\
\hline BJP MP*BJP Vote Share & & & & $\begin{array}{c}-0.923 \\
(0.682)\end{array}$ \\
\hline BJP MP*Square of BJP Vote Share & & & & $\begin{array}{c}0.00970 \\
(0.00779)\end{array}$ \\
\hline Other Controls & \multicolumn{4}{|c|}{ YES (As in Table 2) } \\
\hline District Trends & YES & YES & YES & YES \\
\hline Trend & YES & YES & YES & YES \\
\hline Observations & 147 & 147 & 136 & 136 \\
\hline Number of id & 120 & 120 & 112 & 112 \\
\hline
\end{tabular}

Robust Std. Errors (in parentheses) are clustered at Panchayat Samiti level. *** $\mathrm{p}<0.01,{ }^{* *} \mathrm{p}<0.05,{ }^{*} \mathrm{p}<0.1$ 
Table 5 - Marginal Effect of Vote Share from specification $2 \& 4$ of Table 4

\begin{tabular}{cccccc}
\hline \hline $\begin{array}{c}\text { INC } \\
\text { Vote Share }\end{array}$ & $\begin{array}{c}\text { Without INC } \\
\text { MP }\end{array}$ & $\begin{array}{c}\text { With INC } \\
\text { MP }\end{array}$ & $\begin{array}{c}\text { BJP } \\
\text { Vote Share }\end{array}$ & $\begin{array}{c}\text { Without BJP } \\
\text { MP }\end{array}$ & $\begin{array}{c}\text { With BJP } \\
\text { MP }\end{array}$ \\
\hline \hline \multirow{3}{*}{30} & -0.0421 & -0.2421 & 30 & 0.0204 & -0.3202 \\
& $(0.748)$ & $(0.001)$ & & $(0.785)$ & $(0.127)$ \\
34 & -0.0322 & -0.1577 & 34 & 0.0218 & -0.2411 \\
& $(0.738)$ & $(0.002)$ & & $(0.681)$ & $(0.111)$ \\
38 & -0.0223 & -0.0733 & 38 & 0.0233 & -0.1620 \\
& $(0.725)$ & $(0.011)$ & & $(0.482)$ & $(0.084)$ \\
42 & -0.0124 & 0.0111 & 42 & 0.0248 & -0.0829 \\
& $(0.736)$ & $(0.461)$ & & $(0.216)$ & $(0.036)$ \\
46 & -0.0025 & 0.0955 & 46 & 0.0263 & -0.0038 \\
& $(0.946)$ & $(0.001)$ & & $(0.329)$ & $(0.915)$ \\
50 & 0.0075 & 0.1799 & 50 & 0.0278 & 0.0753 \\
& $(0.906)$ & $(0)$ & & $(0.541)$ & $(0.394)$ \\
\hline
\end{tabular}

$\mathrm{p}$ value in brackets 
TABLE 6 - All the Panchayat Samitis

\begin{tabular}{|c|c|c|}
\hline $\begin{array}{l}\text { Dependent Variable: } \\
\text { Vote share }(2010) \text { /Vote share }(2005) \\
\text { Subscript } 0 \text { refers to Time Period } 0\end{array}$ & $\begin{array}{c}(1) \\
\text { INC- OLS }\end{array}$ & $\begin{array}{c}(2) \\
\text { BJP- OLS }\end{array}$ \\
\hline Funds $_{0}$ & $\begin{array}{c}0.000356^{* * *} \\
(8.28 \mathrm{e}-05)\end{array}$ & $\begin{array}{c}8.43 \mathrm{e}-05 \\
(7.64 \mathrm{e}-05)\end{array}$ \\
\hline Funds $_{0} *$ INC Vote Share ${ }_{0}$ & $\begin{array}{c}-7.71 \mathrm{e}-06^{* * *} \\
(1.74 \mathrm{e}-06)\end{array}$ & \\
\hline Funds $_{0} *$ BJP Vote Share ${ }_{0}$ & & $\begin{array}{c}-2.23 \mathrm{e}-06 \\
(1.83 \mathrm{e}-06)\end{array}$ \\
\hline Total No. of Wards ${ }_{0}$ & $\begin{array}{c}-0.00785^{*} \\
(0.00431)\end{array}$ & $\begin{array}{l}0.00660^{*} \\
(0.00361)\end{array}$ \\
\hline Proportion of Land Irrigated $_{0}$ & $\begin{array}{c}0.0586 \\
(0.0684)\end{array}$ & $\begin{array}{c}0.298^{* * *} \\
(0.103)\end{array}$ \\
\hline Infrastructure Index ${ }_{0}$ & $\begin{array}{c}0.00322 \\
(0.0221)\end{array}$ & $\begin{array}{c}-0.0163 \\
(0.0177)\end{array}$ \\
\hline Total Population 0 & $\begin{array}{c}2.76 \mathrm{e}-07 \\
(2.66 \mathrm{e}-07)\end{array}$ & $\begin{array}{c}1.76 \mathrm{e}-08 \\
(3.29 \mathrm{e}-07)\end{array}$ \\
\hline Proportion of Scheduled Caste ${ }_{0}$ & $\begin{array}{l}-0.152 \\
(0.213)\end{array}$ & $\begin{array}{l}-0.239 \\
(0.209)\end{array}$ \\
\hline Proportion of Females $_{0}$ & $\begin{array}{c}0.450 \\
(1.454)\end{array}$ & $\begin{array}{l}2.421 \\
(2.230)\end{array}$ \\
\hline Proportion of Scheduled Tribe ${ }_{0}$ & $\begin{array}{c}-0.214^{*} \\
(0.110)\end{array}$ & $\begin{array}{c}-0.0673 \\
(0.114)\end{array}$ \\
\hline Proportion of Illiterates $_{0}$ & $\begin{array}{l}-0.0449 \\
(0.340)\end{array}$ & $\begin{array}{l}-0.381 \\
(0.419)\end{array}$ \\
\hline Constant & $\begin{array}{c}0.999 \\
(0.740)\end{array}$ & $\begin{array}{l}-0.130 \\
(1.243)\end{array}$ \\
\hline District Fixed Effects & YES & YES \\
\hline Observations & 219 & 219 \\
\hline R-squared & 0.456 & 0.419 \\
\hline
\end{tabular}


Appendix Table A1: First stage results of 2SLS estimation (Table 2)

\begin{tabular}{lcc}
\hline \hline & \multicolumn{2}{c}{ Dependent Variable } \\
\hline & INC Vote Share & Square of INC Vote Share \\
\cline { 2 - 3 } INC Vote Share (Lagged) & -.525894 & -5.486258 \\
& $(.3315029)$ & $(24.63524)$ \\
Square of INC Vote Share(Lagged) & .0008761 & -.3642984 \\
& $(.0039227)$ & $(.3096237)$ \\
\hline & & \\
Other Covariates & Yes & Yes \\
Panchayat Samiti Fixed Effects & Yes & Yes \\
District Trend & Yes & Yes \\
Time Trend & Yes & 426 \\
No. of Observations & 426 & 19.28 \\
F-statistic & 21.01 & \\
\hline \hline Robust Std. Errors( in parentheses) clustered at Panchayat Samiti level \\
$* * * \mathrm{p}<0.01, * * \mathrm{p}<0.05, * \mathrm{p}<0.1$ & \multicolumn{2}{c}{}
\end{tabular}

Appendix Table A2: First stage results of 2SLS estimation (Table 3)

\begin{tabular}{lcc}
\hline \hline & \multicolumn{2}{c}{ Dependent Variable } \\
\hline & BJP Vote Share & Square of BJP Vote Share \\
\cline { 2 - 3 } BJP Vote Share (Lagged) & .3386811 & $53.95741^{* * *}$ \\
Square of BJP Vote Share(Lagged) & $(.260914)$ & $(18.82677)$ \\
& $-.0085801^{* *}$ & $-1.089338^{* * *}$ \\
& $(.003835)$ & $(.3004294)$ \\
\hline \multirow{2}{*}{ Other Covariates } & Yes & Yes \\
Panchayat Samiti Fixed Effects & Yes & Yes \\
District Trend & Yes & Yes \\
Trend & Yes & Yes \\
No. of Observations & 410 & 410 \\
F-statistic & 4.08 & 8.23 \\
\hline \hline
\end{tabular}

Robust Std. Errors( in parentheses) clustered at Panchayat Samiti level $* * * \mathrm{p}<0.01,{ }^{* *} \mathrm{p}<0.05,{ }^{*} \mathrm{p}<0.1$ 
Appendix Table A3: Marginal Effect of Covariates in Period 0 on the probability of Close Election Panchayat Samitis in Period 1

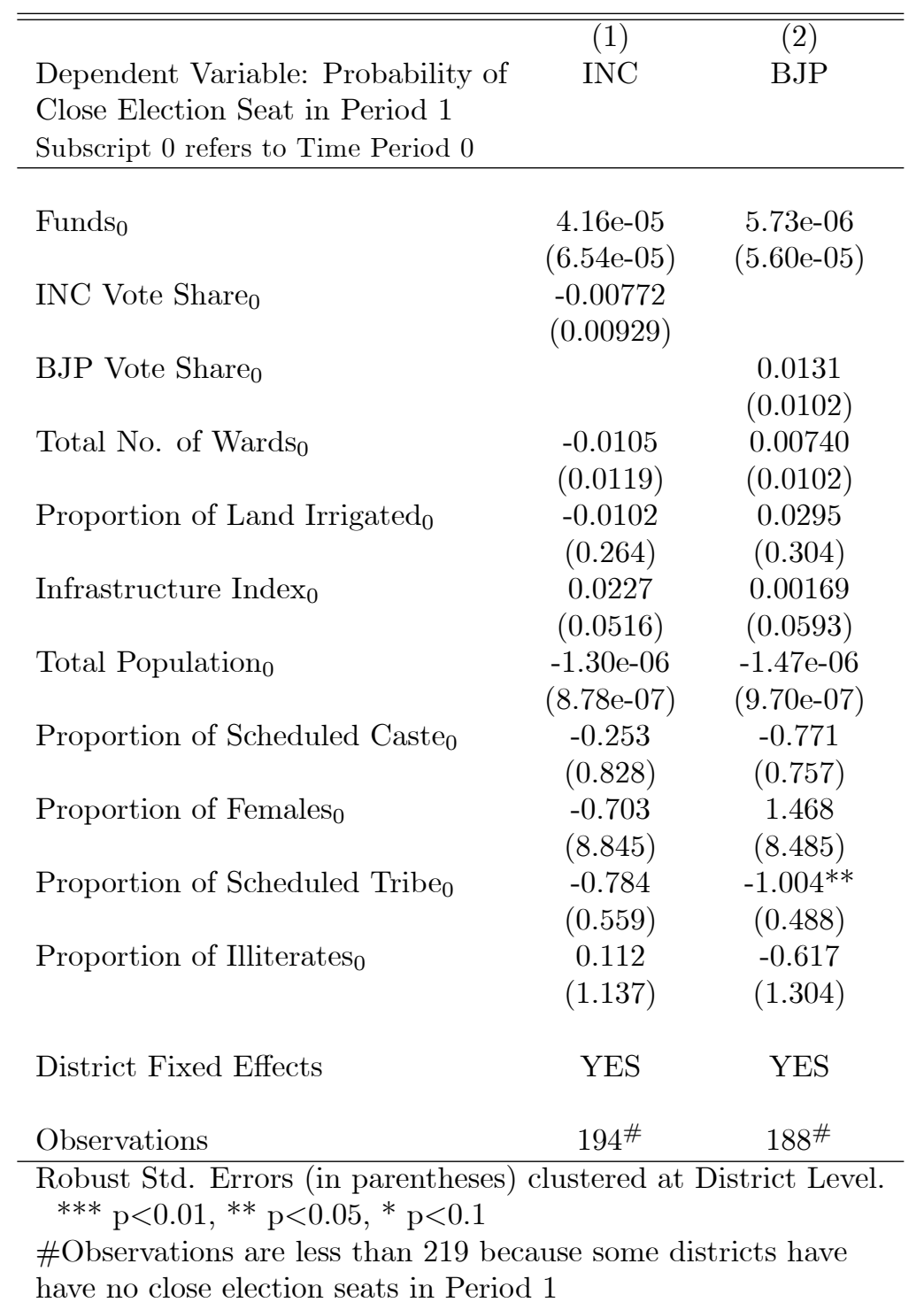




\section{FIGURE 1: TIME PERIOD - I (2005)}

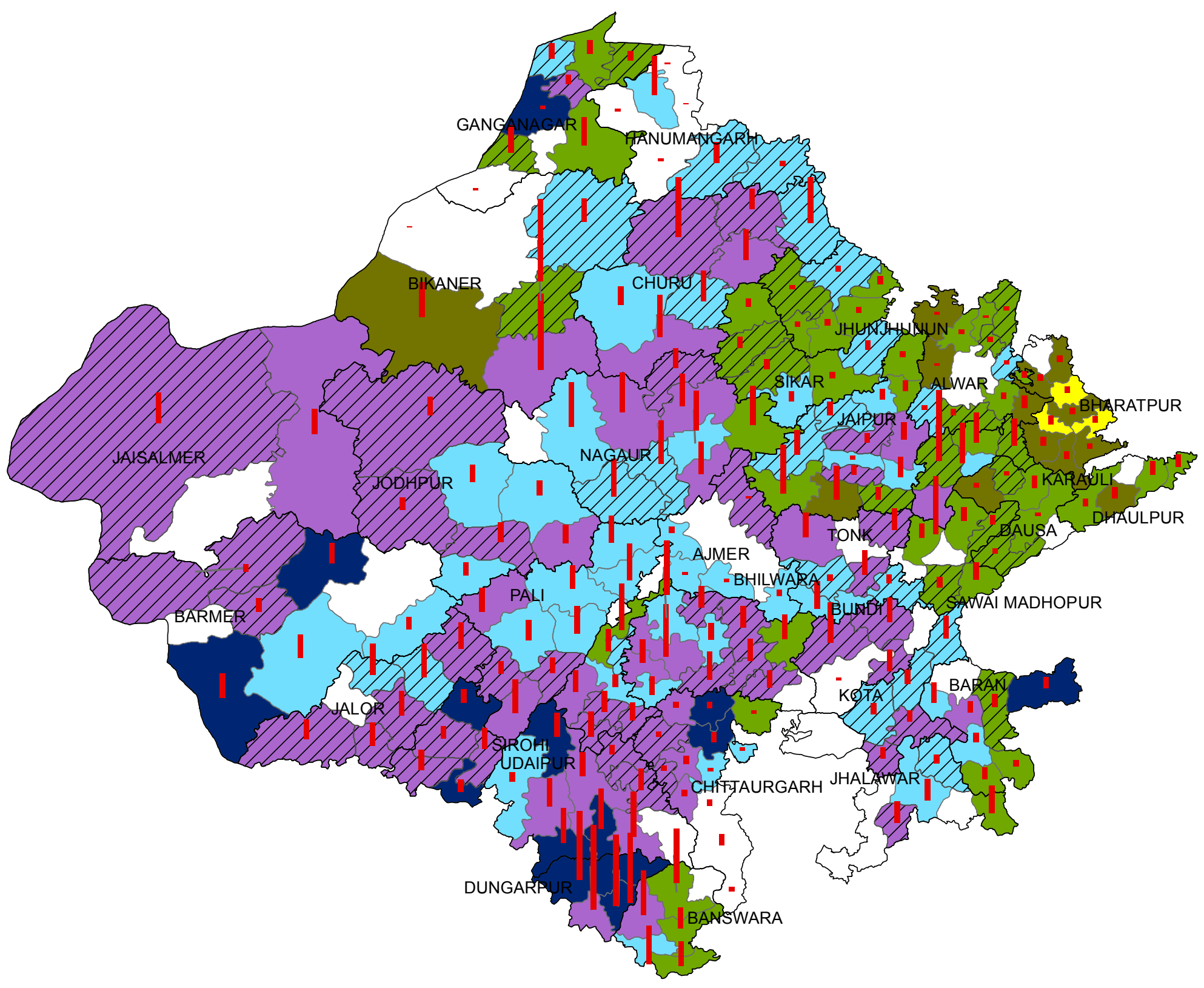

INC Vote Proportion

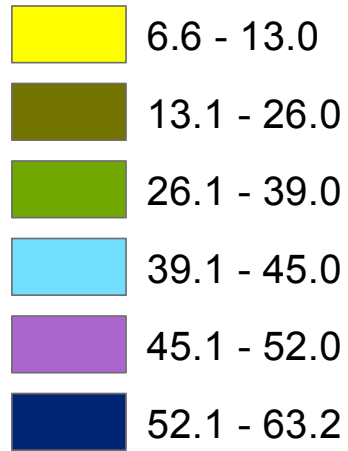




\section{FIGURE 2: TIME PERIOD - II (2010)}

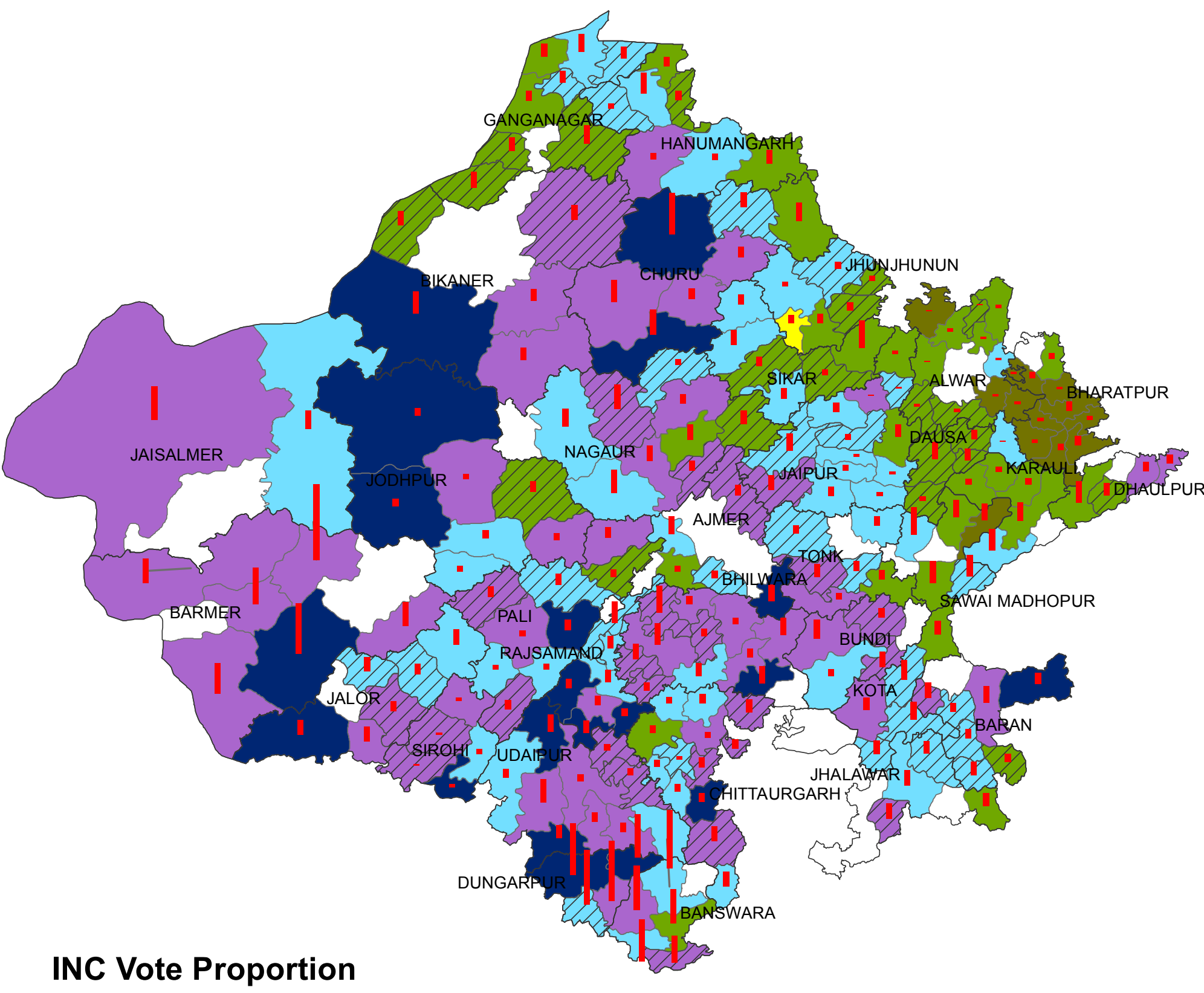

$0.0-13.0$

$13.1-26.0$

$26.1-39.0$

$39.1-45.0$

$45.1-52.0$

$52.1-64.0$
3,000

Funds in Lakhs

$\triangle$ Narrow Margin Seats 
Figure 3

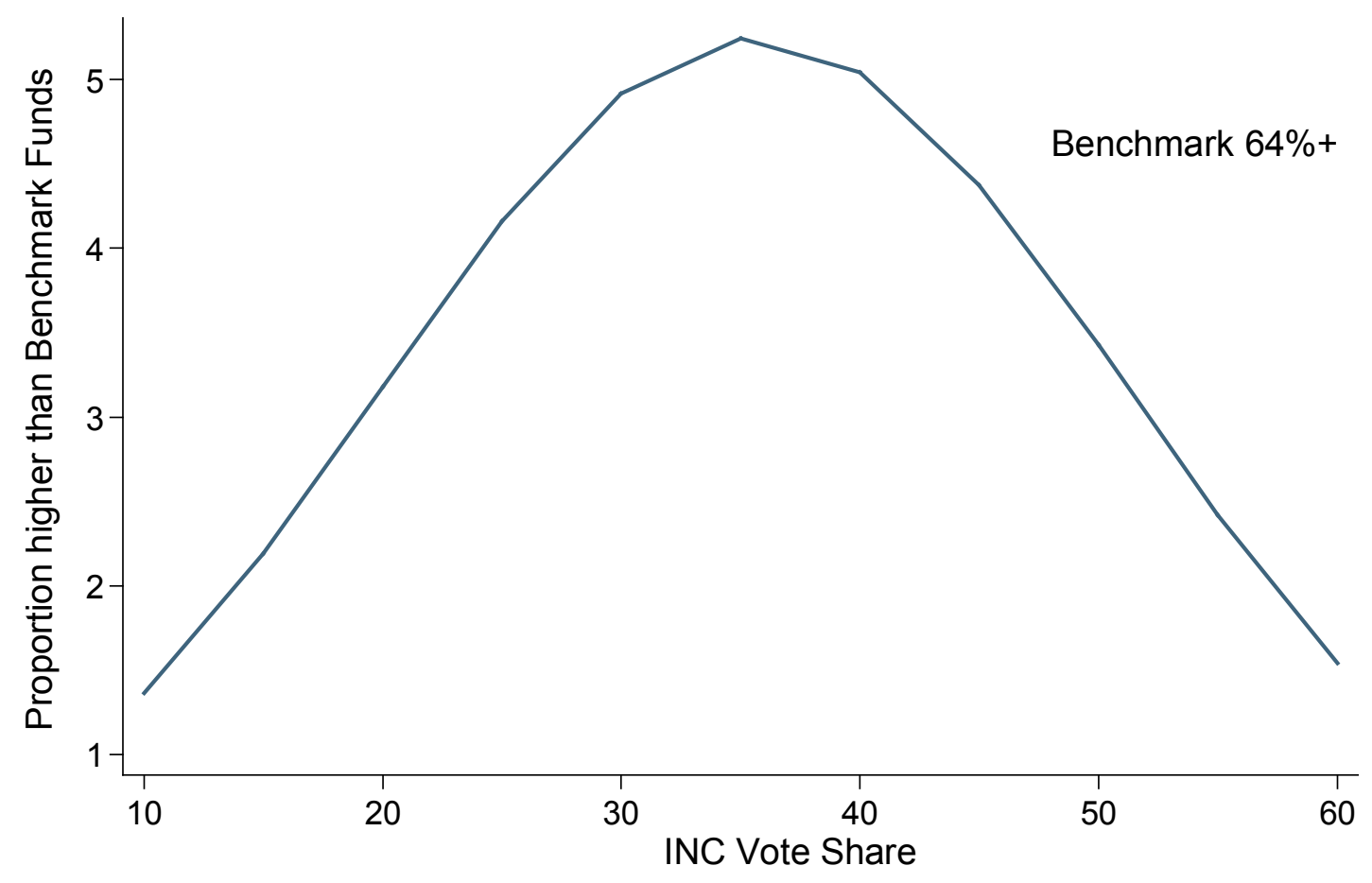

Figure 4

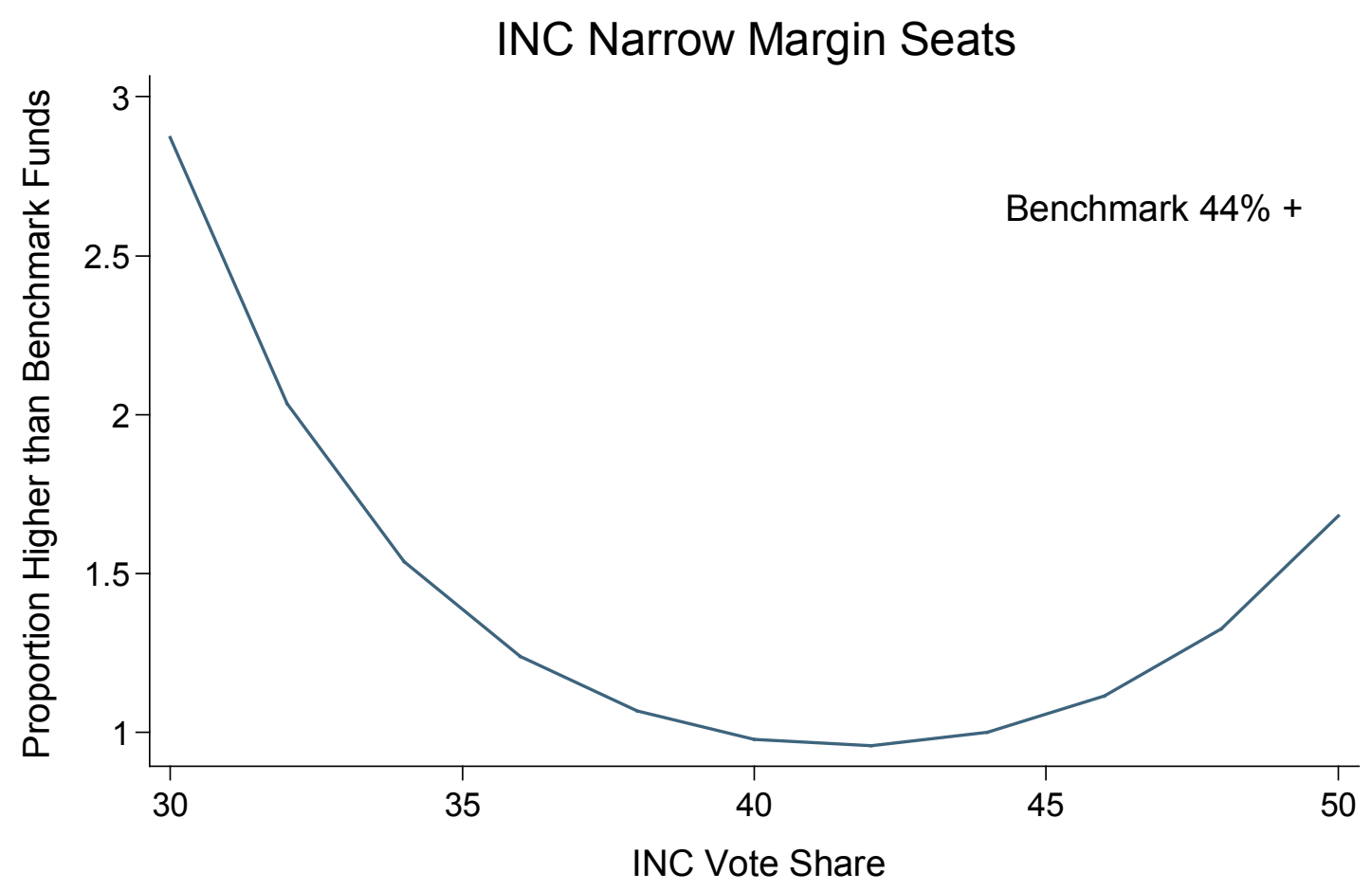


Figure 5

INC Narrow Margin Seats

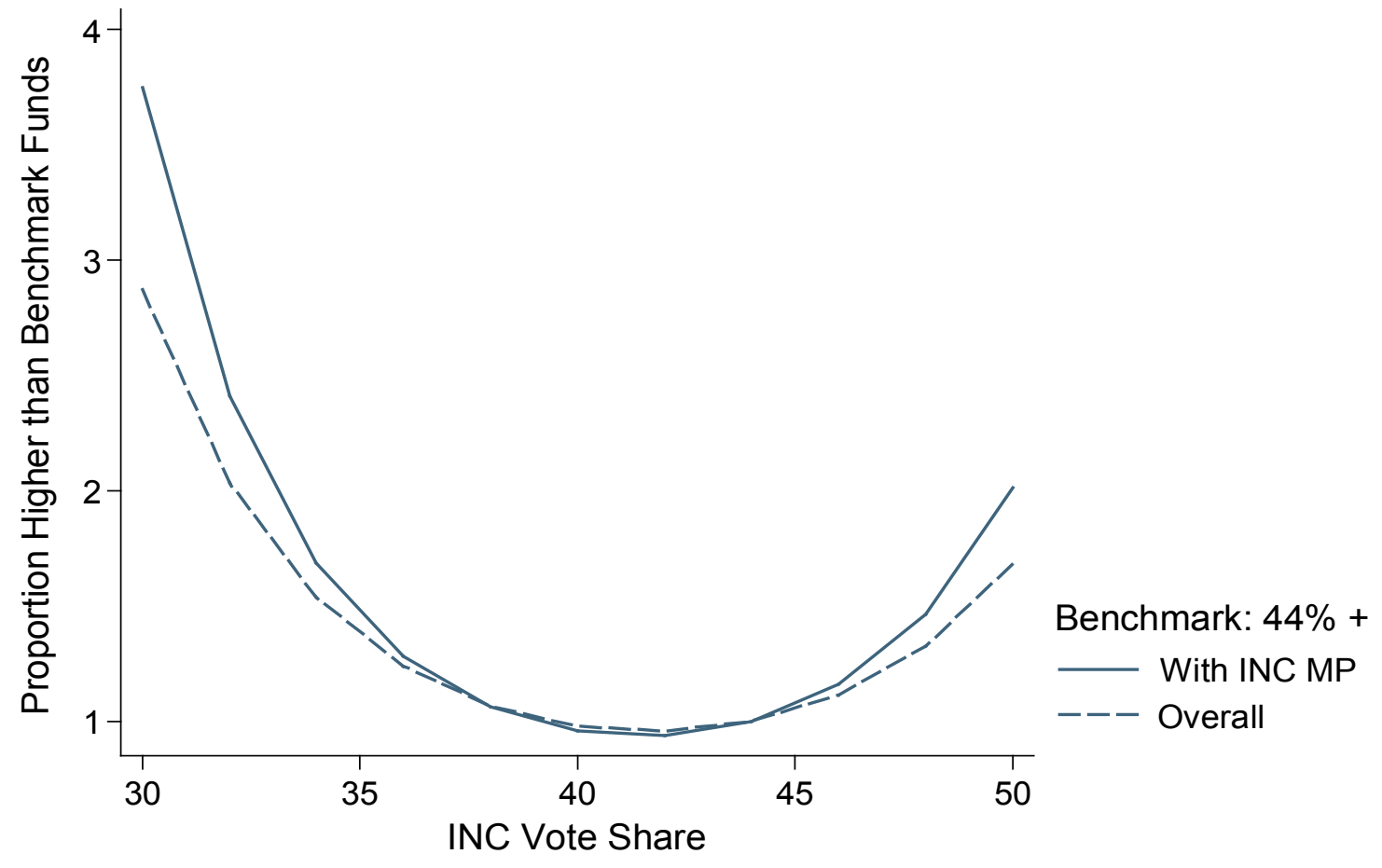

